\title{
POLA ATTACHMENT DAN KUALITAS HUBUNGAN SOSIAL PADA REMAJA YANG TINGGAL DI PANTI ASUHAN
}

\author{
Mutiara Tioni Asprilia dan Zainal Abidin \\ Fakultas Psikologi, Universitas Padjadjaran \\ Jl. Raya Bandung Sumedang KM.21, Hegarmanah, Kec. Jatinangor, Kabupaten Sumedang, Jawa Barat 45363 \\ E-mail: mutiara13006@mail.unpad.ac.id
}

\begin{abstract}
ABSTRAK
Gangguan attachment merupakan efek yang paling jelas terlihat pada anak-anak yang dibesarkan di suatu institusi seperti panti asuhan. Attachment anak dengan pengasuh di usia dini merupakan hal yang penting karena dapat terkait dengan kesehatan emosional, self-esteem, rasa percaya diri, dan kemampuan interaksi sosial yang baik kelak pada saat anak menginjak usia remaja. Meskipun telah dilakukan usaha untuk menjadikan panti asuhan sebagai tempat yang dapat menggantikan peran keluarga biologis, tinggal di panti asuhan menghilangkan kesempatan anak untuk mengalami kehidupan keluarga yang penting bagi anak dalam mengembangkan hubungan sosial yang sehat. Penelitian ini bertujuan untuk mengeksplorasi pola attachment dan kualitas hubungan sosial berdasarkan Social Relations Model (SRM) pada remaja yang tinggal di panti asuhan. Hasil dari penemuan ini dapat dijadikan landasan untuk penelitian lanjutan yang hendak meneliti hubungan sosial anak di panti asuhan. Metode campuran digunakan untuk memperoleh gambaran yang luas mengenai SRM remaja. Data diperoleh melalui wawancara dan kuesioner. Remaja yang tinggal di panti asuhan $(\mathrm{N}=3)$ diminta mengikuti proses wawancara. Data kuantitatif dijabarkan dalam bentuk tabel, dan data kualitatif dijelaskan menggunakan analisis SRM dengan pendekatan fenomenologis. Pada penelitian ini, dua orang responden menunjukkan pola secure attachment dan satu orang dengan pola dismissive attachment. Berdasarkan tipe attachment, terlihat perbedaan pola hubungan sosial. Tipe secure attachment dapat mengekspresikan emosinya dengan mudah dan memandang pengasuh sebagai sosok yang afektif. Tipe dismissive attachment cenderung tidak mudah mengekspresikan emosinya dan tidak memandang pengasuh sebagai sosok yang afektif.
\end{abstract}

Kata kunci: Attachment; Hubungan Sosial; Remaja; Panti Asuhan; Social Relations Model

\section{ATTACHMENT STYLES AND QUALITY OF SOCIAL RELATIONS IN ADOLESCENTS LIVING UNDER INSTITUTIONAL CARE}

\begin{abstract}
Attachment problem is the most visible effect on children raised in institutional care. Early attachment between children and their caregiver is important because it is related to emotional health, self-esteem, self-confidence, and good social interaction skill later in adolescence. Despite the effort to make institutional care a place that could fill in the role of a biological family, children who lived under institutional care lost their chance to experience a family life which is essential in developing healthy social relations. This study aimed to explore attachment styles and the quality of social relations based on the Social Relations Model (SRM) in adolescents living under institutional care. Results of this study can be a foundation for further research related to social relations in children living under institutional care. Mix-method research approach was used to obtain a wide overview of adolescents' SRM. Data was obtained through interview and survey. Adolescents living under institutional care $(\mathrm{N}=3)$ were asked to follow an interview process. Qualitative data were presented in table and qualitative data were explained in SRM analysis with phenomenological approach. Participants of this study showed secure attachment style $(\mathrm{n}=2)$ and dismissive attachment style $(\mathrm{n}=1)$. Based on attachment styles, differences were seen in social relations pattern. Secure attachment style can easily express their emotion and they see their caregiver as an affectionate figure. Dismissive attachment style tends to have difficulty in expressing their emotion and they didn't see their caregiver as an affectionate figure.
\end{abstract}

Kata kunci: Attachment; Social Relations; Adolescence; Institutional Care; Social Relations Model 


\section{PENDAHULUAN}

Indonesia merupakan negara kepulauan terbesar yang menempati peringkat keempat negara dengan populasi tertinggi di dunia dengan 237,5 juta orang penduduk dan termasuk di dalamnya 81,3 juta anak-anak (Badan Pusat Statistik, 2010). Dalam penelitian oleh Kementerian Sosial Republik Indonesia (Kemensos RI) (Save The Children, 2013) yang berkolaborasi dengan Save the Children dan UNICEF, ditemukan bahwa sistem perlindungan anak di Indonesia sangat bergantung pada panti asuhan dengan estimasi 8000 fasilitas tidak teregulasi yang menaungi lebih dari 500.000 anak (Martin \& Sudrajat, 2007). Kebanyakan institusi tersebut dijalankan oleh komunitas atau organisasi religius dan sangat sedikit institusi yang dijalankan oleh Kemensos RI. Penggunaan panti asuhan sebagai bentuk utama dan formal dari intervensi dalam kasus-kasus krisis personal, sosial, dan ekonomi sangat kuat di Indonesia (Martin \& Sudrajat, 2007).

Di negara-negara lain dengan berbagai etnis, budaya, dan latar belakang ekonomi, panti asuhan juga digunakan secara luas untuk merawat anak-anak yang ditelantarkan dan anak-anak yatim piatu (O'Kane \& Lubis, 2016). Menurut Gunnar (2001), institusi dapat diklasifikasikan ke dalam tiga level berdasarkan kualitas perawatan yang mereka sediakan: (1) institusi yang secara umum kurang memenuhi kebutuhan kesehatan, nutrisi, stimulasi dan hubungan dengan anak; (2) institusi dengan dukungan kesehatan dan nutrisi memadai, tetapi kekurangan dalam kebutuhan stimulasi dan hubungan dengan anak; dan (3) institusi yang memenuhi semua kebutuhan kecuali hubungan jangka panjang yang stabil dengan pengasuh yang konsisten. Meskipun terdapat klasifikasi yang berbeda-beda, setiap panti asuhan berupaya dan memiliki tujuan untuk menjadi institusi yang menyerupai keluarga sebenarnya (van Ijzendoorn dkk., 2011)

Kurangnya pengasuhan individual dan lingkungan yang tepat untuk mengembangkan potensi anak merupakan masalah utama yang sering ditemui di panti asuhan. Selain karena kurangnya staf yang bertugas di suatu panti asuhan dibandingkan jumlah anak yang dinaunginya, kurangnya pengasuhan individual juga seringkali disebabkan oleh pengasuh yang kurang dilatih untuk interaksi tersebut. Bahkan pada kondisi optimal ketika pengasuh cukup terlatih dan sedang berinteraksi dengan satu anak, interaksi pengasuh dengan anak dirasakan tidak sama sensitif dengan interaksi anak yang dibesarkan oleh ibu biologis di dalam keluarga (Vorria dkk., 2003). Tanpa sengaja, institusi seringkali membuat anak kehilangan interaksi timbal-balik yang sensitif dengan pengasuh yang stabil.

Semua anak yang dibesarkan di panti asuhan pada satu titik pernah mengalami perpisahan atau kehilangan dengan orang tua biologis mereka atau orang yang mengasuh mereka sebelumnya. Perpisahan dengan pengasuh, terutama pada usia dini ketika anak sedang mengembangkan pola secure attachment dapat mengganggu proses perkembangan attachment tersebut. Ketika anak merasa tidak mendapatkan hubungan lekat yang membuatnya merasa aman dengan pengasuhnya, attachment anak akan berkembang ke arah pola yang insecure. Pola attachment yang terbentuk pada anak ini kelak dapat memengaruhi bagaimana anak merespon dan berinteraksi dengan lingkungannya di usia lebih dewasa. Penelitian Dobrova-Krol, Bakermans-Kranenburg, van Ijzendoorn, \& Juffer (2010) membahas tentang efek dari pengasuhan institusional pada tipe attachment menggunakan Strange Situation Procedure (Ainsworth, Blehar, Waters, \& Wall, 1978). Anak yang tinggal di panti asuhan menunjukkan nilai tinggi pada insecure attachment, khususnya pada pola disorganized attachment. Van Ijzendoorn dkk. (2011) menyimpulkan bahwa gangguan attachment merupakan salah satu efek paling jelas dari pengasuhan di panti asuhan semenjak observasi awal di tahun 1940an.

Dalam proses perkembangannya, anak mengembangkan Internal Working Model (IMW) terhadap attachment. IMW merupakan suatu model mental sederhana yang melibatkan pengasuh, hubungan mereka, dan diri anak sebagai seseorang yang pantas menerima pengasuhan (Santrock, 2011). Model ini juga berperan penting dalam kaitan antar attachment dengan pemahaman emosi, pengembangan hati nurani, dan konsep diri seseorang (Thompson, 2006). Attachment muncul dari ekspektasi anak terhadap perilaku pengasuh. Ekspektasi tersebut kemudian digunakan untuk menentukan kualitas afektif dari hubungan mereka. Attachment awal anak dengan pengasuh penting karena dapat terkait dengan perilaku sosial anak pada tahap perkembangan selanjutnya. Selain itu, attachment awal juga terkait dengan kesehatan emosional (Bakermans-Kranenburg dkk., 2011), self-esteem yang tinggi, kepercayaan diri, dan interaksi sosial yang kompeten dengan teman, guru, dan pasangan romantis kelak pada masa remaja (Santrock, 2011). 
Remaja merupakan masa transisi dari anak-anak menjadi dewasa. Pada masa ini, individu sedang melalui perkembangan pada aspek kognitif, psikososial, dan emosional. Salah satu tugas penting remaja yang terkait dengan kondisi psikososial mereka adalah mengembangkan identitas diri. Berdasarkan fase perkembangan identitas pada remaja (Pfeifer \& Berkman, 2018), usia ini dirasakan peneliti sebagai usia yang cukup tepat untuk melihat pandangan diri remaja dan lingkungannya karena pada usia ini remaja sudah mulai mengembangkan identitas diri. Meskipun perpisahan dengan orang tua dapat menjadi salah satu prediktor terbaik insecure attachment pada remaja (Lewis, Feiring, \& Rosenthal, 2000), dalam GuyonHarris, Humphreys, Fox, Nelson, \& Zeanah (2019) dan McLaughlin, Zeanah, Fox, \& Nelson (2012) dikatakan bahwa attachment awal tidak selalu terkait dengan tipe attachment anak ketika sudah dewasa. Pengasuhan positif yang konsisten seiring berjalannya waktu juga penting dalam menghubungkan attachment awal dengan perkembangan fungsi anak kelak. Anak yang tinggal di panti asuhan mungkin mendapatkan pengasuhan positif demikian, namun mungkin juga tidak. Berangkat dari hal tersebut, peneliti tertarik untuk melihat perjalanan pengasuhan remaja yang tinggal di panti asuhan berdasarkan ingatannya dan melihat pola attachment serta IMW yang terbentuk pada diri remaja. Penelitian menggunakan pendekatan fenomenologis serupa pernah juga dilakukan dalam penelitian Paramitha \& Widiasavitri (2018) dan beberapa penelitian lainnya. Meski demikian dalam penelitian ini, hasil wawancara dengan partisipan akan lebih lanjut dikaji menggunakan Social Relations Model (SRM) (Kenny \& La Voie, 1984) yang merupakan suatu metode dalam mempelajari hubungan diad antar dua orang. Penggunaan SRM sebagai metode untuk menganalisa didasari oleh anggapan bahwa hubungan dasar individu dengan pengasuh utamanya terdiri dari pola interaksi keduanya dalam hubungan diad tersebut.

\section{METODE PENELITIAN}

Institusi. Penelitian dilakukan di salah satu institusi peduli anak yatim piatu terbesar di Bandung yang telah memiliki cabang hingga ke provinsi lain di Indonesia. Remaja yang tinggal di institusi ini kebanyakan ditempatkan oleh anggota keluarga mereka sendiri baik karena kondisi ekonomi maupun tidak adanya pengasuh yang dapat membesarkan anak. Anak-anak remaja yang tinggal di institusi ini pernah mengalami perpisahan dengan orang terdekat mereka, baik pada saat bayi maupun ketika sudah memasuki usia sekolah. Cabang dari institusi di mana penelitian dilakukan menaungi 21 remaja di dalam asramanya, yang mana semuanya saat ini sedang duduk di bangku Sekolah Menengah Atas (SMA). Jalannya kegiatan di asrama diawasi oleh satu orang ibu asrama yang diputar tempat penugasannya setiap beberapa bulan atau tahun.

Partisipan. Usia remaja yang tinggal di asrama cabang tempat penelitian dilakukan berkisar antara 15 hingga 18 tahun. Pemilihan partisipan dilakukan dengan teknik convenience sampling. Setelah melalui proses permintaan kesediaan melalui pihak administrasi dan ibu asrama serta penyerahan surat izin pengambilan data, 3 partisipan remaja bersedia untuk mengikuti proses pengambilan data (usia 16 tahun). Data berhasil diperoleh dari ketiga partisipan dan proses pengambilan data dapat diikuti dengan baik hingga selesai.

Penelitian ini termasuk ke dalam desain penelitian yang fleksibel yaitu dengan menggunakan bentuk penelitian fenomenologi (Hasa, 2017) yang eksploratif dalam usaha menyusun gambaran dari fenomena sebagaimana dialami oleh partisipan. Penelitian dilakukan pada kelompok partisipan secara cross-sectional dengan metode campuran yang mengombinasikan elemen kualitatif dan kuantitatif untuk memperoleh pemahaman yang mendalam terhadap fenomena (Schoonenboom \& Johnson, 2017). Partisipan ditanyakan mengenai kesediaannya untuk mengikuti penelitian ini kemudian diminta untuk mengisi data diri beserta dua buah kuesioner (Adolescent Friendship Attachment Scale \& Inventory of Parents and Peer Attachment) mengenai kondisi attachment mereka terhadap pengasuh dan teman yang nantinya dapat digunakan sebagai data suplemental. Setelah partisipan mengisi kuesioner, proses wawancara terkait attachment dan hubungan sosial partisipan yang umumnya berlangsung 45 menit hingga 1 jam dimulai. Dalam penelitian ini, peneliti ingin melihat perkembangan hubungan partisipan dengan orang-orang terdekatnya semenjak kecil hingga remaja saat ini.

The Friends and Family Interview (FFI). FFI (Pace, 2014) merupakan wawancara semiterstruktur mengenai pengalaman masa kecil yang terkait dengan orang tua atau pengasuh partisipan, pandangan partisipan akan pengaruh dari pengalaman-pengalaman yang ia miliki, dan hubungannya saat 
ini dengan orang tua atau pengasuhnya (Zegers, Schuengel, van Ijzendoorn, \& Janssens, 2006). Partisipan juga diberikan pertanyaan mengenai kehilangan akan orang yang penting baginya dan tentang pengalaman traumatis lainnya. FFI merupakan adaptasi dari Adult Attachment Interview (AAI), namun dianggap lebih tepat diberikan untuk anak berusia 9-16 tahun karena skalanya didasarkan pada kemampuan perkembangan kognitif dari kelompok usia tersebut. FFI juga meliputi pertanyaan mengenai hubungan dengan saudara, teman, dan guru yang sangat penting bagi remaja awal, namun tidak ada pada protokol AAI (Kriss, Steele, \& Steele, 2013).

Adolescent Friendship Attachment Scale (AFAS). Wilkinson (2012; 2008) mengembangkan AFAS, pengukuran self-report terdiri dari 30 item untuk mengukur pertemanan dekat remaja yang mana merupakan konseptualisasi dari hubungan attachment. Pengukuran ini ditujukan untuk anak berusia 13 hingga 19 tahun. Attachment pada hubungan pertemanan digambarkan oleh tiga faktor yang mendasari yaitu secure, anxious/ambivalent, dan avoidant. Subskala AFAS dianggap reliabel dan valid apabila dibandingkan dengan pengukuran gaya attachment ataupun instrumen tes untuk attachment kelompok teman dan orang tua (IPPA).

Inventory of Parents and Peer Attachment (IPPA). Skala yang awal mulanya dikembangkan oleh Armsden \& Greenberg (1987) dan direvisi oleh Gullone \& Robinson (2005) ini mengukur berbagai kualitas dari hubungan anak dengan orang tua (ibu, ayah; atau wali yang memegang peranan ini) dan teman. Kualitas hubungan tersebut dilihat dari hal-hal seperti kepercayaan, kualitas komunikasi, dan perasaan marah serta terasingkan. Setiap kuesioner (ibu, ayah, teman; khusus dalam penelitian ini kuesioner yang digunakan adalah untuk pengasuh dan teman) memiliki 3 subskala. Subskala kepercayaan terdiri dari 10 item, subskala komunikasi terdiri dari 9 item, dan subskala keterasingan terdiri dari 6 item. Skala ini menggunakan skala Likert 1-5 untuk menyatakan sangat tidak sesuai hingga sangat sesuai. Partisipan diminta menandai skala yang paling sesuai dengan dirinya berdasarkan masing-masing item pernyataan yang disajikan. Item yang negatif harus diskor terbalik. Kuesioner ini memiliki reliabilitas yang tinggi (.66$.86)$.

Transkrip wawancara dianalisa menggunakan analisis fenomenologis untuk mengembangkan deskripsi tekstural dari pengalaman partisipan. Analisa data dilakukan dengan membaca masing-masing transkrip wawancara, kemudian dilakukan koding untuk menarik esensi atau unit yang dianggap bermakna dari data. Setelah itu unit-unit yang bermakna diintegrasikan menjadi suatu tema inti. Tema-tema yang didapatkan, selanjutnya ditelaah untuk mencari koneksi dan keterkaitan. Teknik analisis ini digunakan karena dianggap sesuai dengan tujuan dilakukannya penelitian yaitu untuk berusaha memahami pengalaman partisipan dalam hidupnya yang secara berkelanjutan memengaruhi keadaan partisipan saat ini. Masing-masing partisipan tidak diharapkan untuk memberikan jawaban tertentu kecuali pengalaman individu.

Analisis dari transkrip FFI membutuhkan pertimbangan dari konten dan proses narasi yang disampaikan partisipan. Meskipun dimensi yang ingin dilihat sangat dipengaruhi oleh apa yang dikatakan, hal tersebut juga harus dievaluasi dalam hal bagaimana informasi tersebut disampaikan (Kriss dkk., 2013). Memberikan suatu klasifikasi attachment terhadap suatu wawancara merupakan langkah terakhir dari proses koding FFI. Masing-masing klasifikasi dimensional dibuat secara independen sebelum penentuan kategorikal dipertimbangkan. Klasifikasi attachment akhir merepresentasikan strategi dominan partisipan yang diobservasi di dalam transkrip (Kriss dkk., 2013).

Perbedaan dalam kualitas attachment dapat dijelaskan oleh karakteristik dari individu yang melaporkan attachment, karakteristik dari attachment figure, dan karakteristik dari hubungan attachment yang spesifik (Buist, Dekovic, Meeus, \& van Aken, 2004). Oleh karena itu, dirasakan tepat untuk menganalisa data untuk melihat kualitas attachment seseorang melalui Social Relations Model (SRM) (Kenny \& La Voie, 1984) yang mana utamanya melihat kemungkinan kebergantungan dalam perilaku dan persepsi antara dua pasangan dalam suatu interaksi diad. Dalam SRM, actor effects merepresentasikan ratarata kecenderungan seseorang untuk berperilaku dengan gaya tertentu ketika berinteraksi dengan berbagai pasangan. Partner effects pada SRM merupakan sejauh mana individu spesifik cenderung memperoleh respon tertentu dari orang lain. Relationship effects merefleksikan penyesuaian diri khusus dari aktor terhadap partner tertentu, keunikan dari interaksi antara dua orang pada perilaku tertentu, atau dimensi persepsional ketika mengontrol actor \& partner effects (Back \& Kenny, 2010). Secara umum, melalui SRM perbedaan dalam kualitas attachment pada remaja dapat dijelaskan melalui karakteristik orang yang melaporkan attachment, karakteristik attachment figure, karakteristik dari hubungan attachment spesifik, 
atau karakteristik keluarga secara keseluruhan. Dapat juga dilihat apakah kualitas dari attachment saling berbalas pada level individu, diad, atau keduanya (Buist dkk., 2004).

FFI menggunakan beberapa sudut pandang dan konstruk dalam menganalisa data yang diantaranya dengan koherensi, Internal Working Models (IWM), dan Reflective Functioning (RF) dengan memberikan penekanan khusus pada pertimbangan akan konten dan proses dari berbicara ketika menganalisa transkrip. Sampai saat ini, FFI sudah muncul dalam beberapa publikasi artikel penelitian. Sejauh ini FFI telah menunjukkan reliabilitas inter-rater yang kuat dan validitas konstruk dalam komunitas (Kriss, Steele, \& Steele, 2011) dan sampel beresiko (Kriss, Steele, \& Steele, 2012).

\section{HASIL DAN PEMBAHASAN}

\section{Kualitas Hubungan Sosial (SRM) Remaja Putri Panti Asuhan Secara Umum}

Actor effects. Ketika sedih atau kecewa, partisipan cenderung diam dan tidak ingin terlihat oleh orang lain. Hal ini sesuai dengan fase ekspresi emosi remaja yang bersamaan dengan semakin matang perkembangan fisiknya semakin berkurang kedekatan dan kebutuhan untuk diterima dalam hubungannya dengan pengasuh (Flannery, Torquati, \& Lindemeier, 1994). Pada usia 16 tahun, partisipan cenderung untuk tidak membagikan afeknya secara terbuka dengan pengasuh dan lebih banyak membuka diri dengan teman seusianya.

Perpisahan terbesar bagi para partisipan adalah ketika terdapat anggota keluarga yang meninggal dunia. Kematian figur attachment atau orang penting lainnya merupakan suatu kejadian yang dapat memberikan trauma yang cukup signifikan apabila terjadi pada saat individu masih berada pada usia kanakkanak. Anak-anak khususnya rentan terhadap permasalahan psikologis setelah mengalami kejadian traumatis seperti kematian orang yang penting dalam hidup mereka (Osterweis, Solomon, \& Green, 1984). Kejadian traumatis yang sudah berlangsung cukup lama dan terkait dengan tekanan posttraumatic dapat tergambarkan sebagai ingatan yang jelas (Blix, Birkeland, \& Thoresen, 2020). Hal ini dapat menjadi penjelasan terkait ingatan partisipan yang cukup jelasyang dirasakan sebagai perpisahan terbesar berkaitan dengan kejadian anggota keluarga yang meninggal. Berdasarkan wawancara dengan partisipan, ditemukan bahwa pada saat itu respon mereka adalah dengan menangis. Bagi semua partisipan, primary caregiver dianggap sebagai role model yang baik.

Partner effects. Primary caregiver dianggap sebagai orang yang dapat memberikan dukungan dan dapat digantungkan. Hal yang paling disukai dari caregiver adalah ketika sedang saling bertukar cerita. Dalam hal ini, peran pengasuh sebagai primary caregiver telah sesuai dengan apa yang diharapkan dari seorang primary caregiver yang ideal, yaitu sebagai dasar aman dalam anak mengeksplorasi dan belajar tentang dunia (Colmer, Rutherford, \& Murphy, 2011). Teman dekat dianggap sebagai teman yang paling mengerti diri mereka sehingga tahu hal-hal apa saja yang ditunjukkan atau tidak ditunjukkan partisipan kepada orang lain. Sebagaimana dijelaskan dalam Flannery dkk. (1994) bahwa pada usia remaja, afek dengan teman lebih menjadi preferensi dan dirasakan lebih positif daripada dengan pengasuh. Hal ini menjelaskan preferensi partisipan untuk berkeluh kesah terhadap temannya dan merasa lebih dapat dimengerti oleh temannya.

Relationship effects. Primary caregiver merupakan tempat untuk bercerita. Percekcokan yang terjadi antara partisipan dan caregiver hanya sekedar adu argumen dan tidak pernah besar. Partisipan memandang hubungannya dengan caregiver di masa depan akan tetap sama, namun menjadi lebih mandiri karena terpisahkan oleh keadaan. Bagi partisipan, teman dekat merupakan teman yang paling dapat diceritakan berbagai macam hal dan memiliki sifat yang sama dengan mereka. Meskipun hubungan yang positif tetap terjaga dengan pengasuhnya, perubahan dalam gaya interaksi ini dapat dilihat sebagai masa peralihan pada remaja yang mulai mempersepsikan kedekatannya dengan pengasuh utama berkurang dari sebelumnya. Sebagai proses pengembangan diri dan identitas, remaja berusaha memperoleh autonomi terutama dari pengasuhnya (Pfeifer \& Berkman, 2018) dan hal ini terlihat dalam preferensi hubungan partisipan yang lebih mengarah pada teman. 


\section{Kualitas Hubungan Sosial (SRM) Terkait Tipe Attachment (Cherry, 2020) Secure attachment}

Actor effects. Dari pengalaman hidup dengan caregiver nya, partisipan dengan tipe secure attachment merasa memiliki role model yang baik dan menginspirasinya. Melihat pada caregiver-nya, mereka merasa masih perlu belajar untuk lebih peka terhadap orang lain. Saat sedang sedih atau kecewa, partisipan dengan secure attachment mengeskpresikan perasaannya dengan menangis namun tidak mau dilihat oleh orang lain ketika sedang menangis. Ketika mood sedang buruk, biasanya perilaku yang mencerminkan perasaannya ditunjukkan kepada orang-orang di sekitarnya meskipun orang-orang tersebut bukan merupakan sumber emosinya. Pada saat demikian, partisipan dengan secure attachment cenderung lebih sensitif. Ketika menghadapi perpisahan yang dianggap berat, partisipan dengan secure attachment menunjukkannya dengan cara menangis serta menunjukkan penolakan terhadap perpisahan tersebut. Saat kehilangan orang dekatnya, partisipan dengan secure attachment merasa kehilangan tempat bergantungnya. Seiring dengan berjalannya waktu, mereka terkadang masih suka teringat dengan orang tersebut. Berdasarkan data yang diperoleh dari partisipan, dapat dikatakan bahwa seseorang dengan secure attachment cenderung lebih mudah mengekspresikan emosinya dan dapat terlibat secara emosional dalam suatu hubungan dekat. Hal ini sesuai dengan karakteristik seseorang dengan secure attachment yang umumnya mudah untuk membagikan perasaan dan pendapatnya dengan orang lain (Lawson, 2020). Karakteristik secure attachment lainnya yang juga muncul dari pernyataan partisipan adalah sikap terus terang dan menunjukkan kepercayaan serta berbagi keintiman dalam suatu hubungan (Levy \& Davis, 1988).

Partner effects. Primary caregiver dilihat sebagai orang yang dapat memberikan dukungan, dapat digantungkan, dan merupakan orang yang dipandang afektif, misalnya memberikan perhatian. Selain itu caregiver juga dianggap dapat dijadikan sebagai tempat untuk menceritakan berbagai macam hal. Caregiver dianggap dapat menunjukkan perhatian yang lebih kepada partisipan daripada terhadap orang lain. Ketika partisipan dengan secure attachment terluka secara fisik, caregiver menunjukkan perhatian yang lebih besar daripada biasanya. Saat partisipan dengan secure attachment sedih karena perpisahan, mereka biasanya ditenangkan dengan ditunjukkan bahwa masih ada orang lain yang bisa digantungkan. Ketika menghadapi perpisahan yang dianggap berat, caregiver berusaha untuk tidak menunjukkan perasaan sedihnya namun tetap terlihat. Hal yang paling disukai dari caregiver adalah ketika sedang saling bertukar cerita. Hal yang paling tidak disukai adalah ketika caregiver marah. Ketika hal ini terjadi, biasanya respon partisipan dengan secure attachment hanya diam mendengarkan dan hanya sesekali membantah. Berdasarkan apa yang dikatakan partisipan, dapat dikatakan bahwa seseorang dengan secure attachment memandang partnernya dalam suatu hubungan sebagai seseorang yang dapat memberikan dukungan dan perhatian baik dalam hal emosional maupun secara fisik. Cara pandang seseorang dengan secure attachment terhadap partnernya dalam hubungan diad ini sesuai dengan karakteristik hubungan secure attachment sebagaimana disampaikan dalam Levy dan Davis (1988) yaitu hubungan yang bahagia, saling percaya dan bersahabat, juga menerima dan mendukung. Dengan teman dekatnya, hal yang paling disukai adalah ketika sedang bercanda atau bersenang-senang membicarakan apapun. Hal yang tidak disukai adalah ketika mereka terkena imbas dari suasana hati temannya atau temannya keras kepala. Berdasarkan pernyataan partisipan, individu dengan secure attachment mampu menjaga hubungan yang positif dengan teman meskipun terdapat konflik di dalam hubungan tersebut. Kemampuan mempertahankan hubungan pertemanan pada seseorang dengan secure attachment didukung oleh intelegensi emosional yang baik untuk mendukung penyelesaian masalah yang efektif (Lawson, 2020). Partisipan juga menyebutkan kemampuan saling memahami dengan temannya. Hal ini sesuai dengan karakteristik hubungan dengan kepribadian secure attachment di mana terdapat keterampilan empati yang kuat untuk menginterpretasikan tanda-tanda verbal maupun nonverbal dalam berinteraksi (Lawson, 2020).

Relationship effects. Dalam hubungannya, partisipan dengan secure attachment merasa caregiver menunjukkan perhatiannya karena kasihan terhadap keadaan mereka. Ketika terjadi pertengkaran, partisipan dengan secure attachment menganggap percekcokan di antara dirinya dan caregiver hanya sebatas adu argumen dan bukan merupakan sesuatu hal yang besar. Persepsi partisipan sebagai individu dengan secure attachment terhadap permasalahan atau konflik di dalam hubungannya sesuai dengan karakteristik individu dengan secure attachment dalam hubungan yang memiliki kemampuan sangat baik untuk menyelesaikan konflik dan tidak merasa terancam oleh kritik (Lawson, 2020). Individu dengan secure attachment tidak mudah merasa terancam karena seringkali mereka merasa nyaman dengan diri 
mereka sendiri dan merasa nyaman untuk membagikan fakta-fakta pribadi serta perasaan dengan partnernya dalam hubungan untuk mencapai hubungan yang lebih memuaskan bagi kedua pihak (Keelan, Dion, \& Dion, 1998). Selain itu partisipan juga menyatakan bahwa teman dekat merupakan tempat bercerita dan meluapkan emosi. Hubungan ini dirasakan didominasi oleh komunikasi ia dengan teman dekatnya. Hubungan yang penuh berbagi rasa serta komunikasi juga sesuai dengan karakteristik umum dari individu dengan secure attachment dalam hubungan (Lawson, 2020).

\section{Dismissive attachment}

Actor effects. Dari pengalaman hidupnya dengan caregiver, partisipan dengan dismissive attachment belajar untuk peduli terhadap pencapaian (prestasi) dan menyelesaikan masalah dengan logis dan sistematis. Partisipan dengan dismissive attachment juga tidak mudah percaya dengan orang lain. Pada saat sedih atau kecewa, partisipan dengan dismissive attachment tidak ingin diketahui oleh orang lain. Yang ada di dalam pikirannya ketika merasakan hal tersebut adalah bagaimana ia dapat menyelesaikannya. Ketika menghadapi perpisahan yang dianggap berat, partisipan dengan dismissive attachment merasa tidak sedih di awal, namun diperjalanan ia dapat menangis tanpa tahu apa sebabnya. Saat kehilangan orang dekatnya, partisipan dengan dismissive attachment sedih karena membandingkan keadaannya dengan orang lain. Seiring dengan berjalannya waktu, mereka melihat perpisahan dengan cara yang dirasionalisasikan. Secara umum, partisipan dengan dismissive attachment memiliki karakteristik yang tidak terlibat secara emosional dan melihat permasalahan melalui sudut pandang yang rasional. Karakteristik yang muncul sesuai dengan karakteristik individu dengan dismissive attachment yang independen, sangat bergantung pada diri sendiri, dan secara aktif menciptakan jarak dari lingkungan sosial dan hal-hal yang terkait emosi (Baumann \& Scheffer, 2010). Partisipan juga menunjukkan ketidak nyamanannya dalam berbagi perasaan dengan pengasuh. Individu dengan dismissive attachment cenderung menghindari hubungan yang intim dengan partnernya dalam hubungan untuk menghindari berbagi hal-hal yang terlalu emosional (Levy \& Davis, 1988). Selain itu partisipan menunjukkan karakteristik yang tidak mudah percaya dengan orang lain sebagaimana disebutkan dalam Levy dan Davis (1988) bahwa karakter utama dari seseorang dengan dismissive attachment adalah kurangnya rasa percaya terhadap orang lain dan respon natural defensif.

Partner effects. Primary caregiver dilihat sebagai orang yang dapat memberikan dukungan, dapat digantungkan, namun bukan merupakan orang yang dipandang afektif. Primary caregiver lebih dipandang sebagai seseorang yang capable, contohnya adalah berperilaku adil. Partisipan dengan dismissive attachment merasa caregiver menganggap dirinya sebagai anak secara status karena terikat hubungan darah. Hal ini sesuai dengan karakteristik individu dengan dismissive attachment yang pada dasarnya berjarak secara emosional dan kurang terdapat kedekatan (Levy \& Davis, 1988). Mereka dapat menjalin suatu hubungan yang solid dengan orang lain, namun cenderung untuk menghindari hubungan dengan interdependensi emosional yang dalam. Dalam hubungan individu dengan dismissive attachment seringkali tidak terlihat afek dalam interaksi (Flannery dkk., 1994). Ketika partisipan dengan dismissive attachment terluka secara fisik, caregiver biasanya memberikan bantuan padanya tanpa menunjukkan bentuk afeksi yang berbeda. Ketika menghadapi perpisahan yang dianggap berat, caregiver tidak menunjukkan perasaannya saat berpisah. Ketika partisipan dengan dismissive attachment sedih karena perpisahan, mereka ditenangkan dengan cara dibohongi meskipun ia tahu kebenarannya. Pola pengasuhan masa kecil partisipan dengan dismissive attachment ini sesuai dengan masa kecil individu dismissive attachment pada umumnya. Dalam pengasuhan, kurang terdapat cinta dan rasa aman menyebabkan individu tersebut lebih memilih untuk bergantung pada dirinya sendiri (Lawson, 2020). Hal yang paling disukai dari caregiver adalah ketika mereka sedang saling bertukar cerita. Hal yang paling tidak disukai adalah ketika caregiver membahas kekurangan partisipan dengan dismissive attachment yang disadari dimilikinya. Individu dengan dismissive attachment cenderung memiliki ideal yang tidak dapat dipenuhi oleh siapapun (Lawson, 2020). Respons natural mereka adalah defensif (Levy \& Davis, 1988) sehingga hubungan yang mengkritiknya bukan merupakan hubungan yang disukai. Dalam hal teman dekat, hal yang paling disukai adalah ketika ia dan temannya dapat membahas bersama hal-hal yang sama-sama disukai. Hal yang tidak disukai adalah ketika mereka terkena dampak dari suasana hati temannya. Sebagaimana dijelaskan dalam Lawson (2020), individu dengan dismissive attachment dapat menjalin hubungan yang solid seperti pertemanan. Meskipun demikian, mereka tidak menyukai hubungan dengan banyak keterlibatan emosional 
yang dapat membuat mereka terlihat dingin dalam hubungan. Hal ini dapat menjelaskan ketidaksukaan partisipan dengan dismissive attachment ketika perlu menghadapi permasalahan suasana hati temannya.

Relationship effects. Primary caregiver dianggap hanya dapat diceritakan hal-hal tertentu saja karena partisipan bukanlah penerima perhatian "utama". Masalah pribadi dianggap hanya akan membebani caregiver. Partisipan dengan dismissive attachment merasa tidak pernah terjadi percekcokan dengan pengasuhnya. Pengasuh biasanya hanya ada untuk mendamaikan apabila terjadi percekcokan antara partisipan dismissive attachment dengan orang lain. Teman dekat merupakan tempat bercerita, namun tetap tidak semua hal dapat diceritakan kepadanya dan kebersamaan tidak sepenuhnya dinilai melalui komunikasi. Secara umum, individu dengan dismissive attachment mampu menjalin hubungan dengan orang lain. Meski demikian, hubungan yang dijalin oleh individu dismissive attachment cenderung tidak menunjukkan afek ataupun keterlibatan emosional. Individu lebih menjaga jarak dengan partnernya dalam hubungan dan lebih banyak bergantung pada diri sendiri untuk menyelesaikan konflik (Lawson, 2020).

\section{Faktor Lain}

Partisipan yang primary caregiver bukan merupakan nuclear family memiliki tipe attachment yang lebih secure. Pada partisipan yang primary caregiver-nya adalah orang tua kandung, tipe attachment yang ditunjukkan adalah dismissive/insecure-avoidant. Dikatakan oleh Tinsley dan Parke (1987) bahwa terdapat perbedaan perilaku antara orang tua dan kakek nenek dalam interaksinya dengan anak. Nenek kakek dinilai secara signifikan lebih lemah lembut dalam berinteraksi dengan anak apabila dibandingkan dengan orang tua. Namun orang tua dianggap lebih kompeten daripada kakek nenek dalam berinteraksi dengan anak. Hal ini dapat menimbulkan perbedaan afeksi yang dirasakan anak dalam masa perkembangannya. Partisipan yang diaush oleh kakek dan nenek (bukan nuclear family) dalam hal ini mungkin menerima lebih banyak afeksi dalam interaksi sehingga mendukung perkembangan pola attachment yang secure. Sedangkan pada partisipan yang diasuh oleh orang tua langsung dan dalam keadaan yang kurang mendukung mungkin kurang mendapatkan afeksi selama masa perkembangannya, yang mana hal ini dapat mendukung perkembangan pola attachment yang insecure.

\section{Hasil Data Kuantitatif}

Tabel berikut ini menjabarkan skor masing-masing partisipan pada setiap instrumen tes, baik yang utama (FFI) maupun yang suplemental (AFAS \& IPPA) secara kuantitatif. Instrumen tes menjabarkan jenis attachment yang dimiliki masing-masing partisipan serta kualitas aspek-aspek attachment pada partisipan. Skor tipe attachment tertinggi pada masing-masing instrumen tes menggambarkan tipe attachment dominan yang dimiliki oleh partisipan dalam hubungannya dengan orang-orang terdekatnya.

Berdasarkan hasil wawancara menggunakan panduan FFI, dilakukan koding secara kuantitatif dengan memberikan skor akan masing-masing tipe attachment yaitu security, dismissiveness, preoccupation, dan disorganization yang dilihat dari jawaban partisipan terhadap setiap pertanyaan. Skor diberikan dalam skala Likert 1-5 dengan (1) sangat tidak sesuai hingga (5) sangat sesuai dengan tipe attachment yang dimaksud. Skor pada setiap tipe pada masing-masing partisipan kemudian dijumlahkan, lalu dibandingkan total skor antar setiap tipe yang mana yang paling tinggi. Tipe dengan skor paling tinggi pada masing-masing partisipan dianggap sebagai tipe attachment yang dominan. Dapat dilihat berdasarkan tabel 1 bahwa hasil data suplemental yang diperoleh melalui kuesioner mendukung hasil analisa dan koding dari instrumen FFI. Hal ini dapat dilihat dari tipe attachment pada masing-masing partisipan sesuai dengan hasil data suplementalnya.

Selain itu, apabila dilihat dari aspek attachment yang terdiri dari trust, communication, dan alienation dapat dilihat bahwa semua partisipan remaja memiliki kepercayaan yang lebih tinggi terhadap primary caregiver nya daripada terhadap teman dekatnya. Kepercayaan terhadap primary caregiver lebih kuat dikarenakan keberadaan caregiver untuk waktu yang lebih lama dan pengasuhan yang mampu memenuhi kebutuhan remaja semenjak kecil sehingga mendukung terbentuknya suatu kepercayaan (Smetana, 2010). Hal ini juga penting dalam pembentukan suatu gaya attachment kelak. Meski demikian, dalam hal komunikasi semua partisipan memiliki komunikasi yang lebih baik dengan teman dekatnya daripada dengan primary caregiver mereka. Hasil ini sesuai dengan perkembangan remaja yang menunjukkan afek positif lebih besar pada usia ini terhadap teman daripada terhadap orang tua (Flannery dkk., 1994). 


\section{Tabel 1}

Skor Subjek pada Instrumen FFI, AFAS, dan IPPA

\begin{tabular}{|c|c|c|c|}
\hline \multirow{10}{*}{$\begin{array}{l}\text { PARTISIPAN } 1 \\
\text { (SF) }\end{array}$} & \multirow{4}{*}{$\begin{array}{l}\text { The Friends and Family Interview } \\
\text { (FFI) }\end{array}$} & Security & 55 \\
\hline & & Dismissiveness & 44 \\
\hline & & Preoccupation & 30 \\
\hline & & Disorganization & 33 \\
\hline & \multirow{3}{*}{$\begin{array}{l}\text { Adolescent Friendship Attachment } \\
\text { Scale (AFAS) }\end{array}$} & Secure & 3.61 \\
\hline & & Anxious/Ambivalent & 2 \\
\hline & & Avoidant & 2.62 \\
\hline & \multirow[t]{3}{*}{$\begin{array}{l}\text { Inventory of Parents and Peer } \\
\text { Attachment (IPPA) }\end{array}$} & $\begin{array}{l}\text { Trust } \\
\text { (caregiver/teman) }\end{array}$ & $4.2 / 3.7$ \\
\hline & & $\begin{array}{l}\text { Communication } \\
\text { (caregiver/teman) }\end{array}$ & $3.22 / \mathbf{3 . 6 2}$ \\
\hline & & $\begin{array}{l}\text { Alienation } \\
\text { (caregiver/teman) }\end{array}$ & $1.16 / 1.71$ \\
\hline \multirow{10}{*}{$\begin{array}{l}\text { PARTISIPAN } 2 \\
\text { (RAJ) }\end{array}$} & \multirow{4}{*}{$\begin{array}{l}\text { The Friends and Family Interview } \\
\text { (FFI) }\end{array}$} & Security & 67 \\
\hline & & Dismissiveness & 26 \\
\hline & & Preoccupation & 46 \\
\hline & & Disorganization & 35 \\
\hline & \multirow{3}{*}{$\begin{array}{l}\text { Adolescent Friendship Attachment } \\
\text { Scale (AFAS) }\end{array}$} & Secure & 4.30 \\
\hline & & Anxious/Ambivalent & 1.66 \\
\hline & & Avoidant & 3.25 \\
\hline & \multirow[t]{3}{*}{$\begin{array}{l}\text { Inventory of Parents and Peer } \\
\text { Attachment (IPPA) }\end{array}$} & $\begin{array}{l}\text { Trust } \\
\text { (caregiver/teman) }\end{array}$ & $4.5 / 4.5$ \\
\hline & & $\begin{array}{l}\text { Communication } \\
\text { (caregiver/teman) }\end{array}$ & $3.11 / 4.5$ \\
\hline & & $\begin{array}{l}\text { Alienation } \\
\text { (caregiver/teman) }\end{array}$ & $2.5 / 1.85$ \\
\hline \multirow{10}{*}{$\begin{array}{l}\text { PARTISIPAN } 3 \\
\text { (RN) }\end{array}$} & \multirow{4}{*}{$\begin{array}{l}\text { The Friends and Family Interview } \\
\text { (FFI) }\end{array}$} & Security & 41 \\
\hline & & Dismissiveness & 72 \\
\hline & & Preoccupation & 26 \\
\hline & & Disorganization & 46 \\
\hline & \multirow{3}{*}{$\begin{array}{l}\text { Adolescent Friendship Attachment } \\
\text { Scale (AFAS) }\end{array}$} & Secure & 3.69 \\
\hline & & Anxious/Ambivalent & 2.55 \\
\hline & & Avoidant & 3.75 \\
\hline & \multirow[t]{3}{*}{$\begin{array}{l}\text { Inventory of Parents and Peer } \\
\text { Attachment (IPPA) }\end{array}$} & $\begin{array}{l}\text { Trust } \\
\text { (caregiver/teman) }\end{array}$ & $4.6 / 4$ \\
\hline & & $\begin{array}{l}\text { Communication } \\
\text { (caregiver/teman) }\end{array}$ & $3.55 / 3.87$ \\
\hline & & $\begin{array}{l}\text { Alienation } \\
\text { (caregiver/teman) }\end{array}$ & $1.66 / 2$ \\
\hline
\end{tabular}

Dalam penelitian ini, eksplorasi hasil analisis fenomenologi menunjukkan gambaran dari tipe attachment dan kualitas hubungan sosial pada remaja yang tinggal di panti asuhan. Remaja membawa perbedaan yang cukup luas mengenai pandangan terhadap hubungannya dengan teman serta caregivernya. Berdasarkan klasifikasi secara kuantitatif dari hasil wawancara, ditemukan bahwa 2 orang partisipan memiliki tipe attachment dominan secure dan 1 orang dismissive. Ditambah dengan kuesioner suplemental, remaja juga mengestimasikan kualitas dari kedekatan mereka dengan caregiver serta teman dekat. Dari wawancara dan kuesioner, dapat dikatakan bahwa hubungan yang remaja anggap afektif dan dekat merupakan hubungan di mana mereka dapat memiliki kepercayaan yang tinggi.

Dalam memandang hubungan dari sudut pandang dirinya, remaja melihat bahwa caregiver merupakan role model dalam hidupnya. Remaja dengan secure attachment merasa dapat menunjukkan apapun yang dirasakannya secara aman kepada orang-orang terdekatnya dan remaja dengan dismissive attachment mengekspresikan perasaannya tanpa ingin diketahui oleh orang lain serta cenderung berusaha menyelesaikan masalah dengan logika. Dari sudut pandang co-actor dalam hubungan, caregiver merupakan orang yang dapat memberikan dukungan dan dapat digantungkan saat dibutuhkan serta orang 
yang paling memahami diri mereka. Remaja dengan secure attachment merasa bahwa caregiver merupakan orang yang dapat memenuhi kebutuhan afektif yang terutama adalah memberikan perhatian lebih, sedangkan remaja dengan dismissive attachment merasa meskipun caregiver dapat digantungkan, caregiver tidak dipandang sebagai sosok yang afektif melainkan capable secara fungsional. Hal ini sesuai dengan karakteristik yang umumnya ditunjukkan oleh individu dengan gaya secure maupun dismissive attachment. Dari sudut pandang hubungan yang dimiliki, remaja merasa kekhasan dari hubungannya adalah tempat saling bertukar cerita dan meskipun terjadi percekcokan tidak pernah menjadi pertengkaran besar sehingga mereka memandang bahwa hubungan mereka dengan orang tersebut tidak akan banyak berubah di masa depan. Remaja yang secure beranggapan bahwa selain tempat bercerita, teman merupakan tempat meluapkan emosi dan hubungan mereka didominasi dengan komunikasi. Pada remaja dengan dismissive attachment, meskipun hubungan dianggap sebagai tempat bercerita, namun mereka tetap memilah mana yang perlu mereka ceritakan dan hubungan dengan teman tidak dinilai berdasarkan komunikasinya. Ia dan temannya dapat duduk diam-diaman dan hal tersebut tidak apa menurut remaja dismissive attachment. Pola ini juga sesuai dengan pola masing-masing tipe attachment pada umumnya di mana gaya secure attachment dapat dengan mudah membagikan perasaannya sedangkan gaya dismissive attachment cenderung menhindari kedekatan emosional.

Social Relations Model (SRM) merupakan suatu pendekatan untuk mempelajari bagaimana seseorang mempersepsikan orang lain. Persepsi akan orang lain merupakan komponen penting dari interaksi sosial. Seseorang harus mempersepsikan karakteristik orang lain secara tepat agar ia dapat memperidiksi bagaimana orang tersebut akan berperilaku. Selain itu, mengetahui apa yang dipikirkan orang lain tentang diri mereka juga penting. Karakteristik remaja yang melaporkan mengenai hubungan dan karakteristik dari hubungan itu sendiri merupakan penjelasan paling penting untuk perbedaan dalam kualitas attachment dan hubungan sosial. Berdasarkan data yang diperoleh dari partisipan penelitian ini, remaja cenderung mendeskripsikan hubungan mereka dengan caregiver atau teman dekatnya dalam hal bagaimana mereka menganggap partner mereka tersebut. Caregiver bagi remaja merupakan seorang role model dan hal-hal yang disukai remaja dari orang terdekatnya cenderung karena mereka dapat dijadikan tempat bercerita dan meluapkan emosi daripada perhatian yang dikatakan mereka peroleh dari partner dalam hubungan. Fokus terhadap peran orang lain dalam memenuhi kebutuhan remaja ini sesuai dan mendukung SRM remaja yang dianggap ideal, yaitu mereka lebih melihat pada faktor dirinya sebagai actor dalam suatu hubungan. Hal ini juga didukung oleh teori perkembangan remaja di mana pada saat ini remaja memiliki adolescent egocentrism yaitu kepercayaan bahwa orang lain sangat memperhatikan perilaku dan penampilan mereka (Galanaki, 2017).

Dalam analisis makna yang diperoleh dari pernyataan-pernyataan partisipan dengan tipe secure attachment maupun dismissive attachment, ditemukan gambaran dari kualitas hubungan sosial yang mereka miliki. Remaja menganggap bahwa caregiver selain merupakan seorang role model yang baik merupakan tempat untuk bercerita. Meski demikian, ketika melihat pada masing-masing pernyataan dapat ditemukan beberapa perbedaan individu. Baik pada aspek actor, partner, maupun relationship, remaja dengan secure attachment beranggapan bahwa mereka selalu memiliki seseorang ataupun sesuatu yang dapat dijadikan tempat bergantung. Hal ini menunjukkan kesesuaian dengan karakteristik secure attachment yang mudah bergantung pada orang lain dan tidak ragu untuk meminta bantuan (Levy \& Davis, 1988). Sedangkan pada remaja dengan dismissive attachment memiliki anggapan bahwa mereka harus selalu dapat mandiri dan menyelesaikan segala sesuatu dengan logika. Karakter pada tipe dismissive attachment ini juga menunjukkan kesesuaian karakter yang sangat bergantung pada dirinya sendiri dalam menyelesaikan permasalahan (Lawson, 2020). Perbedaan juga terlihat dari hubungan remaja dengan teman dekatnya. Remaja dengan secure attachment meluapkan semua emosi dan dapat menceritakan segala hal pada teman dekatnya sedangkan remaja dengan dismissive attachment cenderung memilah apa yang dapat diceritakannya terhadap teman dekatnya. Berdasarkan King (2017), seseorang dengan secure attachment memiliki hubungan yang penuh kepercayaan dan bertahan lama, cenderung memiliki self-esteem yang baik, nyaman membagikan perasaannya dengan partner dan teman, dan mencari dukungan sosial. Lain halnya dengan seseorang yang memiliki dismissive attachment. Mereka dapat memiliki permasalahan dengan keintiman, berkontribusi minim secara emosional dalam hubungan sosial dan romantis, serta tidak mau membagikan pikiran atau perasaannya dengan orang lain. Dengan data yang diperoleh, remaja dengan secure attachment sesuai dalam hal kenyamanannya membagikan perasaan serta pencarian dukungan sosial 
dari orang-orang terdekatnya. Remaja dengan dismissive attachment juga sesuai dalam hal ketidak inginannya membagikan perasaan serta kontribusi emosinya yang kecil dalam suatu hubungan.

Melalui wawancara ini ditunjukkan bahwa dengan panduan, remaja dapat merefleksikan hubungan sosial mereka dengan orang-orang terdekatnya. Kesadaran remaja akan kualitas hubungannya dengan orang-orang terdekatnya secara tidak langsung dapat menjadi dukungan sosial baginya yang mana juga dapat meningkatkan kesehatan emosional, self-esteem, kepercayaan diri, dan interaksi sosial yang kompeten dengan teman, guru, dan pasangan romantis. Penelitian lebih lanjut dapat dilakukan untuk mengidentifikasi apakah kualitas hubungan sosial remaja memiliki dampak terhadap kesejahteraan remaja secara keseluruhan.

\section{SIMPULAN}

Penelitian ini menunjukkan bahwa remaja yang tinggal di panti asuhan beragam dalam hal gaya attachment dan kualitas hubungan sosialnya dengan orang-orang terdekatnya. Remaja dengan tipe secure attachment menunjukkan kesesuaian dengan karakteristik tipe attachment tersebut yaitu dalam hal keterbukaannya dalam membagikan dan mengekspresikan perasaan dengan orang lain. Remaja dengan tipe dismissive attachment juga menunjukkan kesusaiannya dengan karakteristik tipe dismissive attachment, yaitu dalam hal kebergantungan dengan diri sendiri dan kurangnya keinginan untuk terlibat secara emosional dalam suatu hubungan. Hal ini dapat menjadi pertimbangan dalam memberikan pengasuhan atau menjalin hubungan sosial dengan mereka. Membicarakan mengenai hubungan remaja dengan orangorang di sekitarnya membantu remaja untuk melihat kembali dan merefleksikan dirinya beserta orangorang di sekitarnya, yang mana pada dasarnya hal ini sulit untuk disadari oleh remaja itu sendiri. Hasil yang ditemukan dari penelitian fenomenologis ini menguatkan teori yang sudah ada terkait karakteristik dari tipe secure attachment dan dismissive attachment. Hasil dari penelitian ini dapat digunakan untuk mengembangkan cara-cara bagi remaja untuk mengekspresikan dirinya dan memiliki kualitas hubungan sosial yang lebih baik serta bagaimana orang terdekat di sekitarnya dapat memberikan respon timbal balik terhadap remaja yang disesuaikan dengan kondisi tertentu dari remaja. Meski demikian, penelitian lebih lanjut dengan ukuran sampel yang lebih besar dibutuhkan untuk memastikan bahwa hasil penelitian dan interpretasi yang dibuat dapat digeneralisasikan terhadap populasi remaja secara umum.

\section{DAFTAR PUSTAKA}

Ainsworth, M. D. S., Blehar, M. C., Waters, E., \& Wall, S. (1978). Patterns of Attachment. Hillsdale: Lawrence Erlbaum Associates.

Armsden, G. C., \& Greenberg, M. T. (1987). The Inventory of Parent and Peer Attachment: Individual Differences and Their Relationship to Psychological Well-Being in Adolescence. Journal of Youth and Adolescence, 16, 427-454. https://doi.org/https://doi.org/10.1007/BF02202939

Back, M. D., \& Kenny, D. A. (2010). The Social Relations Model: How to Understand Dyadic Processes. Social and Personality Psychology Compass, 4(10), 855-870. https://doi.org/https://doi.org/10.1111/j.1751-9004.2010.00303.x

Badan Pusat Statistik. (2010). Piramida Penduduk Indonesia. Retrieved from https://sp2010.bps.go.id/index.php/site/index

Bakermans-Kranenburg, M. J., Steele, H., Zeanah, C. H., Muhamedrahimov, R. J., Vorria, P., DobrovaKrol, N. A., ... Gunnar, M. R. (2011). Attachment and Emotional Development in Institutional Care: Characteristics and Catch-Up. Monograph of the Society for Research in Child Development, 76(4), 62-91. https://doi.org/10.1111/j.1540-5834.2011.00628.x

Baumann, N., \& Scheffer, D. (2010). Seeing and Mastering Difficulty: The Role of Affective Change in Achievement Flow. Cognition \& Emotion, 24(8), 1304-1328. https://doi.org/https://doi.org/10.1080/02699930903319911

Blix, I., Birkeland, M. S., \& Thoresen, S. (2020). Vivid Memories of Distant Trauma: Examining the Characteristics of Trauma Memories and the Relationship with the Centrality of Event and Posttraumatic Stress 26 Years After Trauma. Applied Cognitive Psychology, 34(3), 678-684. https://doi.org/https://doi.org/10.1002/acp.3650 
Buist, K. L., Dekovic, M., Meeus, W. H., \& van Aken, M. A. G. (2004). Attachment in Adolescence: A Social Relations Model Analysis. Journal of Adolescent Research, 19(6), 826-850. https://doi.org/https://doi.org/10.1177/0743558403260109

Cherry, K. (2020). The Different Types of Attachment Styles. Retrieved March 29, 2021, from Verywell Mind website: https://www.verywellmind.com/attachment-styles-2795344

Colmer, K., Rutherford, L., \& Murphy, P. (2011). Attachment Theory and Primary Caregiving. Australasian Journal of Early Childhood, 36(4), 16-20. https://doi.org/https://doi.org/10.1177/183693911103600403

Dobrova-Krol, N. A., Bakermans-Kranenburg, M. J., van Ijzendoorn, M. H., \& Juffer, F. (2010). The Importance of Quality of Care: Effects of Perinatal HIV Infection and Early Institutional Rearing on Preschoolers' Attachment and Indiscriminate Friendliness. Journal of Child Psychology and Psychiatry, 51(12), 1368-1376. https://doi.org/10.1111/j.1469-7610.2010.02243.x

Flannery, D. J., Torquati, J. C., \& Lindemeier, L. (1994). The Method and Meaning of Emotional Expression and Experience during Adolescence. Journal of Adolescent Research, 9(1), 8-27. https://doi.org/ttps://doi.org/10.1177/074355489491003

Galanaki, E. P. (2017). Adolescent Egocentrism. In Sage Encyclopedia of Abnormal and Clinical Psychology. Retrieved

from https://www.researchgate.net/publication/316554607_Adolescent_egocentrism/stats

Gullone, E., \& Robinson, K. (2005). The Inventory of Parent and Peer Attachment--Revised (IPPA-R) for Children: A Psychometric Investigation. Clinical Psychology \& Psychotherapy, 12(1), 67-79. https://doi.org/https://doi.org/10.1002/cpp.433

Gunnar, M. (2001). Effects of Early Deprivation. In Handbook of Developmental Cognitive Neuroscience (pp. 617-629). Cambridge: MIT Press.

Guyon-Harris, K. L., Humphreys, K. L., Fox, N. A., Nelson, C., \& Zeanah, C. H. (2019). Signs of Attachment Disorders and Social Functioning among Early Adolescents with a History of Institutional Care. Child Abuse \& Neglect, 88, 96-106. https://doi.org/10.1016/J.CHIABU.2018.11.005

Hasa. (2017). Difference Between Case Study and Phenomenology. Retrieved from Pediaa website: https://pediaa.com/difference-between-case-study-and-phenomenology/

Keelan, J. P. R., Dion, K. K., \& Dion, K. L. (1998). Attachment Style and Relationship Satisfaction: Test of a Self-Disclosure Explanation. Canadian Journal of Behavioural Science/Revue Canadienne Des Sciences Du Comportement, 30(1), 24-35. https://doi.org/https://doi.org/10.1037/h0087055

Kenny, D. A., \& La Voie, L. (1984). The Social Relations Model. Advances in Experimental Social Psychology, 18, 141-182. https://doi.org/https://doi.org/10.1016/S0065-2601(08)60144-6

King, L. A. (2017). The Science of Psychology: An Appreciative View. New York: McGraw-Hill Education.

Kriss, A., Steele, H., \& Steele, M. (2011). Attachment Concordance and Discordance in Sibling Relationships: Towards A New Theoretical Model. The Biannual International Attachment Conference. Oslo.

Kriss, A., Steele, H., \& Steele, M. (2012). Thinking Laterally: Sibling and Peer Relationship Quality Predicts Academic Success in Minority Children at Risk for School Dropout. The Society for Research in Child Development Themed Meeting: Positive Development of Minority Children. Tampa.

Kriss, A., Steele, H., \& Steele, M. (2013). Measuring Attachment and Reflective Functioning in Early Adolescence: An Introduction to the Friends and Family Interview. Research in Psychotherapy: Psychopathology, Process and Outcome, 15(2), 87-95. https://doi.org/10.7411/RP.2012.009

Lawson, D. (2020). Mental Health Workbook. Weare: Independently Published.

Levy, M. B., \& Davis, K. E. (1988). Lovestyles and Attachment Styles Compared: Their Relations to Each Other and to Various Relationship Characteristics. Journal of Social and Personal Relationships, 5(4), 439-471. https://doi.org/https://doi.org/10.1177/0265407588054004

Lewis, M., Feiring, C., \& Rosenthal, S. (2000). Attachment over Time. Child Development, 71(3), 707720. https://doi.org/10.1111/1467-8624.00180

Martin, F., \& Sudrajat, T. (2007). Someone That Matters: The Quality Care in Child Care Institutions in Indonesia. Retrieved from https://resourcecentre.savethechildren.net/node/2988/pdf/2988.pdf

McLaughlin, K. A., Zeanah, C. H., Fox, N. A., \& Nelson, C. (2012). Attachment Security as a Mechanism 
Linking Foster Care Placement to Improved Mental Health Outcomes in Previously Institutionalized Children. Journal of Child Psychology and Psychiatry, 53(1), 46-55. https://doi.org/10.1111/j.14697610.2011.02437.x

O'Kane, C., \& Lubis, S. (2016). Alternative Child Care and Deinstitutionalisation: A Case Study of Indonesia.

Retrieved

from http://www.socialserviceworkforce.org/system/files/resource/files/Alternative-Child-Care.pdf

Osterweis, M., Solomon, F., \& Green, M. (1984). Bereavement During Childhood and Adolescence. In Bereavement: Reactions, Consequences, and Care. Retrieved from https://www.ncbi.nlm.nih.gov/books/NBK217849/

Pace, C. S. (2014). Assessing Attachment Representations among Adoptees during Middle Childhood and Adolescence with the Friend and Family Interview (FFI): Clinical and Research Perspectives. Frontiers in Psychology, 5, 1114. https://doi.org/10.3389/fpsyg.2014.01114

Paramitha, H., \& Widiasavitri, P. N. (2018). Gambaran Kelekatan pada Remaja Akhir Putri di Panti Asuhan Tunas Bangsa Denpasar. Jurnal Psikologi Udayana, 5(2), 518-535. https://doi.org/https://doi.org/10.24843/JPU.2018.v05.102.p19

Pfeifer, J. H., \& Berkman, E. T. (2018). The Development of Self and Identity in Adolescence: Neural Evidence and Implications for a Value-Based Choice Perspective on Motivated Behavior. Child Development Perspectives, 12(3), 158-164. https://doi.org/10.1111/cdep.12279

Santrock, J. W. (2011). Child Development (13th ed.). New York: McGraw-Hill Humanities.

Save The Children. (2013). Changing The Paradigm. Retrieved from https://resourcecentre.savethechildren.net/sites/default/files/documents/cc_changing_final1.pdf

Schoonenboom, J., \& Johnson, R. B. (2017). How to Construct a Mixed Methods Research Design. Kölner Zeitschrift Für Soziologic Und Sozialpsychologie, 69, 107-131. https://doi.org/10.1007/s11577-0170454-1

Smetana, J. G. (2010). The Role of Trust in Adolescent-Parent Relationships: To Trust You is to Tell You. Interpersonal Trust During Childhood and Adolescence, 223-246. https://doi.org/10.1017/CBO9780511750946.011

Thompson, R. A. (2006). The Development of the Person: Social Understanding, Relationships, Conscience, Self. In Handbook of child psychology: Social, emotional, and personality development (pp. 24-98). Hoboken: John Wiley \& Sons, Inc.

Tinsley, B. J., \& Parke, R. D. (1987). Grandparents as Interactive and Social Support Agents for Families with Young Infants. The International Journal of Aging and Human Development, 25(4), 259-277. https://doi.org/https://doi.org/10.2190/91M7-1JMA-UQV6-0VH3

van Ijzendoorn, M. H., Palacios, J., Sonuga-Barke, E. J. S., Gunnar, M. R., Vorria, P., McCall, R. B., ... Juffer, F. (2011). Children in Institutional Care: Delayed Development and Resilience. Monograph of the Society for Research in Child Development, 76(4), 8-30. https://doi.org/10.1111/j.15405834.2011.00626.x.

Vorria, P., Papaligoura, Z., Dunn, J., van Ijzendoorn, M. H., Steele, H., Kontopoulou, A., \& Sarafidou, Y. (2003). Early Experiences and Attachment Relationships of Greek Infants Raised in Residential Group Care. Journal of Child Psychology and Psychiatry, 44(8), 1208-1220. https://doi.org/10.1111/1469-7610.00202

Wilkinson, R. B. (2008). Development and properties of the Adolescent Friendship Attachment Scale. $\begin{array}{llll}\text { Journal of Youth and } & \text { Adolescence, 37(10), }\end{array}$ https://doi.org/http://dx.doi.org/10.1007/s10964-006-9141-7

Wilkinson, R. B. (2012). Measuring Attachment Dimensions in Adolescents: Development and Validation of the Experiences in Close Relationships - Revised - General Short Form. Journal of Relationships Research, 2(1), 53-62. https://doi.org/10.1375/jrr.2.1.53

Zegers, M. A. M., Schuengel, C., van Ijzendoorn, M. H., \& Janssens, J. M. A. M. (2006). Attachment Representations of Institutionalized Adolescents and Their Professional Caregivers: Predicting the Development of Therapeutic Relationships. American Journal of Orthopsychiatry, 76(3), 325-334. https://doi.org/https://doi.org/10.1037/0002-9432.76.3.325 